\title{
A LUTA PELO DIREITO: DEBATES SOBRE O SUFRÁGIO FEMININO NA REVISTA DE CRÍTICA JUDICIÁRIA NO INÍCIO DO SÉCULO XX
}

Stéphani Fleck da Rosa ${ }^{1}$

Resumo: Através da análise da Revista de Crítica Judiciária, evidencia-se um repositório de discussões políticojurídicas e sua crítica em um momento de transição e de transformações no conturbado cenário brasileiro do início do século XX. Estuda-se o debate sobre a luta das mulheres brasileiras pelo direito ao voto, pelo viés delineado do campo jurídico e, principalmente, pelos argumentos da primeira advogada do Brasil, Myrthes de Campos. O sufrágio feminino foi pautado em diversos países em períodos anteriores, notoriamente pela luta da igualdade entre gêneros e a composição das mulheres como cidadãs. $\mathrm{O}$ direito ao voto mostrou-se como primeiro passo em direção à libertação jurídica das mulheres do seio da família patriarcal, a qual possui seus papéis de gênero fortemente definidos e sem suportar modificações à época. Mais um aspecto que se delineia neste artigo são as reivindicações femininas serem interpretadas a partir de um recorte de social privilegiado, no qual apenas as mulheres com determinado grau de escolaridade poderia ter acesso ao voto, segundo alguns juristas daquele tempo, o que evidencia ainda mais a importância de um sufrágio que inclua todas as mulheres como será defendido na Revista. Por conseguinte, revive-se a importância de uma fonte esquecida ao direito contemporâneo repleto de rasas coletâneas sobre o passado jurídico nacional, fortalecendo o descompasso crítico da história do direito brasileiro diante de sua trajetória contada em linha reta de atos, fatos e resultados vencedores.

Palavras-Chave: Sufrágio Feminino; Revista de Crítica Judiciária; História do Direito;
Abstract: Through the analysis of the Crítica Judiciária Journal, a repository of political-juridical discussions and their criticism is revealed in a moment of

\footnotetext{
${ }^{1}$ Graduada e Mestre pela Faculdade de Direito da UFRGS.
} 
transition and transformation in the troubled Brazilian scenario of the early twentieth century. The debate on the struggle of Brazilian women for the right to vote, the bias delineated from the legal field and, mainly, by the arguments of the first Brazilian lawyer, Myrthes de Campos, is studied. Women's suffrage was ruled in several countries in previous periods, notably by the struggle of gender equality and the composition of women as citizens. The right to vote was shown as a first step towards the legal liberation of women from the bosom of the patriarchal family, which has its gender roles sharply defined and without undergoing modifications at the time. Another aspect that is outlined in this article are the feminine claims to be interpreted from a privileged social scenario, in which only women with a certain degree of schooling could have access to voting, according to some jurists of that time, which shows even more the importance of a suffrage that includes all women as will be defended in the Journal. Therefore, the importance of a forgotten source of contemporary law replete with shallow recollections of the national juridical past strengthens the critical mismatch of the Brazilian legal history in the face of its straight course of acts, facts and results of winner's version.

Key-words: Woman Suffrage; Crítica Judiciária Journal; Legal History;

\section{Introdução}

$\mathrm{O}$ presente artigo objetiva analisar o debate do sufrágio feminino como um debate de um grupo intelectual restrito, que dada à perspectiva histórica se partiu da Revista de Crítica Judiciária, editada no início do século XX, visando ao enriquecimento e ao aprofundamento das perspectivas da história do direito brasileiro, visto ao comprometimento de utilizar uma fonte esquecida ao direito atual. Ingressa-se com o uso do método dedutivo, através da análise e da consulta aos artigos da Revista.

No primeiro tópico aborda-se a importância da Revista de Crítica Judiciária no seu tempo, como um compêndio de debates jurídicos. Buscase demonstrar o papel da Revista como veículo para o diálogo e composição de crítica entre os operadores do direito à época, evidenciando sua influência na formação de opinião dos mesmos, especialmente na introdução do debate sobre o voto feminino.

No segundo tópico centra-se na 
posição da mulher e da sua luta pelo sufrágio no período inicial do século XX, pela perspectiva predominante intelectualmente no campo jurídico: o positivismo. Neste pensamento é notória a defesa da rigidez dos papéis sociais de gênero, singularmente dentro da esfera familiar, justificando ainda mais o poderio patriarcal no aprisionamento da mulher ao claustro, como o "anjo do lar". Além de esclarecer a situação real das mulheres neste cenário, nas quais eram caladas, sem qualquer direito que não os que eram tratadas como incapazes e sem qualquer iniciativa na sociedade como indivíduo livre, raros os casos de mulheres que conseguiam, dentro de seu privilégio econômico e social, ter a sorte de estudar e obter graus elevados de escolaridade.

No terceiro tópico adentra-se nos debates da Revista de Crítica Judiciária a fim de compor a análise do campo jurídico sobre o voto feminino, tendo como expoente, a primeira advogada do Brasil, Myrthes de Campos. Neste debate mais uma vez traz a mentalidade da época alicerçada na mentalidade dos juristas da época na defesa dos privilégios machistas e patriarcais na tentativa de impedir a concessão do direito ao voto às mulheres.

\section{A Revista de Crítica Judiciária e sua importância ao meio jurídico na primeira metade do século $\mathrm{XX}$}

Criada em novembro de 1924 no Rio de Janeiro por notórios juristas de seu tempo, como Clóvis Beviláqua, Spencer Vampré, Virgilio Barbosa, Nilo C. L. de Vasconcellos, Cesar C. L. de Vasconcellos e pelo desembargador Vieira Ferreira, a Revista de Crítica Judiciária representou na primeira metade do século XX um expoente de formação doutrinária pontuada pela criticidade no que tange a prática jurídica em todo o território brasileiro.

A Revista de Crítica Judiciária percorreu 15 anos de publicação, no período que se estendeu de novembro de 1924 a abril de 1940, totalizando 152 exemplares publicados nesse período, com forte preocupação de abordar casos de outras regiões não centrais do país, fora do eixo Rio de Janeiro e São Paulo. Esse ecletismo é visto também quanto à escolha dos temas tratados na Revista, pela busca de um ineditismo nos julgados a serem comentados e uma orientação mais apropriada, muitas vezes contra senso e respaldados pela doutrina 
estrangeira, para a solução dos mesmos.

Sua primeira publicação foi em novembro de 1924, a qual contou com temas sobre o território nacional, responsabilidade do Estado por danos da população amotinada à propriedade particular, reintegração requerida conta esbulhador sem dependência de instauração de processo, requisitos indispensáveis à denúncia, entre outros (REVISTA CRÍTICA JUDICIÁRIA, 1924, p. 2). Temas pertinentes à realidade daquele tempo, no qual passava por perturbações republicanas, como mesmo aponta no periódico das revoltas locais contra o poder central.

Essa publicação apresentou na primeira parte o seu programa editado por Clóvis Beviláqua e demais artigos sobre doutrina escritos pelo Desembargador Vieira Ferreira e Nilo Vasconcellos. Já a segunda parte se divide nas sessões nomeadas Supremo Tribunal Federal, Appellação Civel, Côrte de Appellação, com comentários sobre julgados destes órgãos, Juizes Singulares, apresentando os melhores desempenhos à época dos juízes em suas comarcas pelo Brasil, comentados pela Revista, e Os grandes julgados, neste mesmo intuito de apresentar um julgado de referência aos magistrados
(REVISTA CRÍTICA JUDICIÁRIA, 1924 , p. 2-25). Tem-se a terceira parte, mais livre editorialmente, mostra a opinião dos editores, que se divide em Resenha do Mês e Secção Livre (REVISTA CRÍTICA JUDICIÁRIA, 1924, p. 25-37). E uma quarta parte, composta por um espaço para propagandas, tanto para assinatura da própria Revista, quanto encomendas de pareceres aos editores, de livros, bem como de propagandas da esfera jurídica.

Essa edição de 1924 vê-se que a Revista tinha por finalidade principal colaborar com a magistratura brasileira à época com a aplicação do direito vigente, impugnando ou defendendo as decisões judiciais, sem desconsiderar o estudo de história e filosofia jurídica. Em Nosso Programma a direção da Revista, ao considerar a importância dos estudos de outras áreas do direito, reforça que há um vínculo indestrutível entre o pensamento de uma época a outros pensamentos no passado, contribuindo, assim, para uma projeção futura das idealizações jurídicas (REVISTA CRÍTICA JUDICIÁRIA, 1924, p. 2). Ao final dessa introdução, apresenta-se o público alvo do periódico, composto pelos advogados e juízes do Brasil, visto que urge a necessidade de se compor um 
esclarecimento diferenciado destes frente a outros componentes da sociedade brasileira.

Segue-se a esta introdução, o artigo A jurisprudência e a critica dos julgados, de autoria do célebre jurista Clóvis Beviláqua, no qual releva a jurisprudência, como resultado da aplicação do direito aos fatos ocorrentes, tornando a lei mais flexível no atendimento à realidade da vida, observando suas limitações, e a crítica, como uma norteadora da compreensão de pontos sólidos dos julgados, além de combater os desvios de doutrina e as interpretações infundadas, encaminhando-se, assim, para uma realização plena da justiça. $\mathrm{O}$ que demonstra, pois, nessas considerações do autor, os direcionamentos da Revista no âmbito de sua análise. Ademais, há a consideração da influência de outros campos de conhecimento no entendimento e na operação do direito, conforme acentua o autor em artigo:

A doutrina, a legislação comparada, a história, a philosophia, a economia política, as artes e as sciencias, todas concorrem para revelar o direito tal como é, quer refulja na letra da lei, sobre a qual se prejectem esses feixes de luz, quer se affirme, egualmente imperativo, ao lado ou além della, condensando os principios, que a vida social suggere para regulamento das acções humanas (REVISTA DE CRÍTICA JUDICIÁRIA, v.1, n.1, novembro 1924, RJ, p.5).

Clóvis Beviláqua, que a época foi mentor do Projeto do Código Civi de 1916 e catedrático na Faculdade de Direito de Recife, apresentou-se como um interlocutor da publicação do periódico, entre os diferentes extratos do campo jurídico, isto é, um espaço social dentro da noção de sistema de autoreferência das estruturas legais, que se transforma segundo as suas próprias leis, propiciando a representação formal e abstrata desse sistema (BOURDIEU, 2001, p. 209).

Já em Interpretação da lei nos julgamentos presente no mesmo volume da Revista, Nilo C. L. de Vasconcellos questiona a não aplicação imediata da lei em vigor, por considerar que essa prática enfraquece moralmente o poder jurídico da lei (REVISTA CRÍTICA JUDICIÁRIA, 1924, p. 8-9). Não obstante, atenta o autor ao fato do abuso pelos juízes da sua amplitude decisória ao ingressar no direito já constituído, apenas por suas arguições pessoais ou 
doutrinárias. E, ao citar as classificações referenciais de interpretação das leis feitas por Clóvis Beviláqua aos juízes, conclui Vasconcellos que sem contestar as prerrogativas dos magistrados em suprir as deficiências jurídicas do texto, estes não devem exercer o papel do poder legislativo. Esse artigo, igualmente ao artigo anterior, ditam possíveis diretrizes de análise dos julgados que deveriam ser seguidas pelos componentes e colaboradores da Revista, principalmente, aos magistrados, como seu público leitor.

Veem-se nesses artigos aspectos metodológicos como o da neutralidade dos intérpretes da lei e da consideração de outras influências doutrinárias e da própria realidade à interpretação das leis, demostrando uma conjugação e não concorrência do direito e outras áreas, consoante apregoa o periódico carioca. A interpretação dada pela Revista possui ditames claros que respeitam um rigor metodológico positivista, sem, no entanto, ignorar o fato social e de sua mutabilidade temporal e dimensão empírica. Desse modo, esse posicionamento interpretativo demonstra desde já uma defesa da Revista à aplicação de correntes jurídicas atualizadas com diálogo com a realidade daquele período ao direito brasileiro, bem como à discussão das fontes do direito estrangeiro, a fim de contribuir para um aperfeiçoamento doutrinário e jurisprudencial do próprio direito nacional.

A publicação se segue nos anos subsequentes, com edições mensais, mantendo a mesma divisão apresentada na primeira Revista com algumas pequenas variações. Publicou-se até abril de 1940, sem apresentar publicação no ano de 1938, não há menção pelo editorial o motivo de tal ausência, o que se pode considerar a justificativa desse lapso no periódico a instauração do Estado Novo naquele mesmo ano, uma vez que os editores durante o Governo Provisório (1930-1934) se mostraram defensores do Estado Democrático de Direito nas resenhas da Revista. Alguns exemplos dessa defesa democrática e preservação das instituições expõem-se nas frases escritas em cabeçalhos e rodapés da publicação, tais como, "Para os postos judiciários, a escolha de homens de cultura e reputação basta como estímulo ao paiz na obra ingente de sua reconstrução", "A vida de uma Nação repousa na boa distribuição da Justiça", "Solicitar cargos judiciários é dar provas de ineptidão moral para 
exercê-los", "A reforma nos quadros da judicatura deve inspirar-se em tais sentimentos cívicos capazes de esquecer amigos e injunções políticas", “É impossível a realização da justiça sem que o magistrado se integre na observância de seus deveres", "Na classificação dos candidatos a juiz fundam-se os moldes da futura justiça", “A unidade da Justiça será o elo mais forte da unidade nacional”, "O Direito não é só ideia, mas também poder de ação", "A justiça é o sangue social”, " $O$ Estado é a resultante da ordem jurídica" (REVISTA CRÍTICA JUDICIÁRIA, 1924-). Ressalta-se, assim, a contrariedade do editorial da Revista de Crítica Judiciária a uma obsolescência burocrática da Justiça com formas ditatoriais de governo, vislumbrando um futuro de privações e censuras.

Logo, a publicação ostra sua preocupação com a direção da Constituinte neste período conturbado, a exemplo da frase na Resenha de outubro de 1933, "A voz de São Paulo, na Constituinte, deverá ser ouvida e acatada como reflexo da tradição histórica do civilismo da cultura, e da educação material do Brasil de amanhã" (REVISTA CRÍTICA JUDICIÁRIA, 1933, p. 22).
Há também o apoio da Revista à recém-criada na época Ordem dos Advogados Brasileiros, expostas em frases e matérias, tais como "Prestigiar a Ordem dos Advogados é dever de profissional que tem o respeito por si mesmo", "A Ordem levará o advogado à altura de uma autoridade judiciária" e “A Ordem dará ao advogado o prestígio de que carece" (REVISTA CRÍTICA JUDICIÁRIA, 1924-). Percebe-se o intuito de formação de grupo social, a partir de uma valoração da instituição criada, também em consonância com a proteção das instituições democráticas.

Diante dessas frases coletadas em suas edições, vê-se no periódico carioca a nítida intenção de ser uma formadora de opiniões, influenciando os operadores do direito, mais ainda por mostrar um direcionamento dos debates políticos e sociais de sua época, com frases de ordem e concepções definidoras do modo de pensar e agir por parte dos editores ao seu público leitor. Além disso, demonstra-se a conexão desse editorial com os grupos de poder da época de uma recente e frágil República Brasileira, especialmente devido à vinculação de partes da classe jurídica, como os magistrados aos mandos políticos e seus consignados, 
visto que o Poder Judiciário brasileiro ainda carecia de autonomia frente à esfera política.

Desde já se compreende a Revista de Crítica Judiciária como um repositório de debates provocadores e acolhedores de mudanças sociais, não apenas no âmbito jurídico, como se verá em seu apoio ao sufrágio feminino, dando voz e autoridade de sua defesa, a primeira advogada do país.

\section{A mulher e o seu sufrágio no Brasil no início do século XX}

Para melhor entendimento da luta pelo voto feminino, inicia-se a descrição do cenário brasileiro pelos últimos anos do Império marcados por grandes e significativas mudanças nos campos econômico, social e político, as quais contribuíram para a instauração do regime republicano. Vê-se que tais mudanças ocorreram impulsionadas pela lavoura cafeeira, onde o café era o principal produto de exportação, oportunizando um maior desenvolvimento do Brasil.

Desenvolvimento este que marcado pela construção de mais ferrovias e melhoramento dos portos para melhor atender à demanda da produção com o
8

transporte do café. Outro aspecto, foi gradativa substituição do trabalho escravo pelo livre, visto com os imigrantes, tendo por consequência o êxodo rural que contribuiu para o crescimento das cidades e para a implementação de novos setores na economia nacional, como a indústria, que se aproveitou da grande oferta de mão-de-obra.

O país teve um crescimento econômico e precisava, assim, de um sustentáculo político e doutrinário que atendesse às suas necessidades, organizando-o e garantindo sua modernização, ao mesmo tempo em que se opunha à corrupção e ao desperdício de recursos instaurados pela desde a monarquia brasileira. Desse modo, na busca de uma nova realidade política alguns grupos organizaram-se a partir do ideário Liberal; outros, no Positivismo fundamentado em Auguste Comte, ou suas variantes em Laffitte e Littré. Esses ideais influenciaram grande parte dos intelectuais brasileiros, como Clóvis Bevilacqua, tanto por seu caráter teóricofilosófico como pelo teor republicano, ao enfatizar que o sistema de governo monárquico deveria ser destituído em nome do progresso, pois apenas seria alcançado através da consolidação da 
República, regime que melhor representa esta fase positivista de governança ideológica nacional.

No entanto, ao que se refere à defesa dos direitos das mulheres, a influência positivista, quanto ao papel da mulher na sociedade, é definitiva e restritiva na eleição da mulher como a guardiã dessa ideologia, a qual reforça a mentalidade baseada na moral conservadora e tinha como objetivo tirar a mulher do campo profissional e científico, enclausurando-a em sua própria casa, com alegação de que ela era um ser irracional e não tinha controle de seus próprios impulsos. Consolidou-se, pois, a imagem da mulher presa ao lar e tutelada pelo homem, pois apenas, assim, a mulher poderia exercer uma influência positiva ao seu meio (ISMÉRIO, 1995, p. 45).

\section{O positivismo e Comte} elegeram a mulher como guardiã da moral e dos bons costumes, anulando sua participação no espaço público, tolhendo sua atuação no campo profissional. A mulher, segundo essa ideologia predominante na intelectualidade brasileira à época, deveria seguir os modelos de rainha do lar e anjo tutelar, para conduzir com dignidade sua família (ISMÉRIO, 1995, p. 48). Essa concepção é vista, infelizmente, de forma tão enraizada na sociedade, que ainda hoje é possível ver seus resquícios, de formas mais sofisticadas, do papel da mulher como instrumento da sua própria casa e do homem.

Quanto à participação política através do voto no início do século XX, em muitos casos, a própria mulher considerava que a mulher casada não deveria votar, pois o marido a representava e com isso estaria evitando conflitos domésticos. O direito ao voto seria restrito apenas à mulher solteira e que trabalhasse para prover seu sustento, justificava-se, pois, as mulheres solteiras não teriam as "alegrias de um casamento feliz muito menos da maternidade $e$ somente lhe restava a participação política" (ISMÉRIO, 1995, p. 49) . Assim, via-se esse direito ao voto, como algo vitimador e excludente para a mulher que o buscava:

Mas se olharem em torno de si, verão que $\mathrm{o}$ número de mulheres que não tem família própria aumenta consideravelmente. Os homens sentem cada vez menos, inclinação para o casamento, a mulher isolada não é mais um fenômeno. Trabalha estuda faz sua carreira corajosamente com os esforços dignos de consideração: procura na vida outras satisfações e outras ideias quando os mais poéticos 
sentimentos lhe são negados. Então porque negar à mulher culta, à mulher madura, possuindo individualidade jurídica, os direitos que se concedem à gente inferior e rude, na maioria dos casos inconscientes da missão confiada aos legisladores? (F. C. O Voto Feminino. POA, KODAK, 1914, p.6).

Com o período republicano e suas mudanças no cenário econômico, a instabilidade mostrou-se propulsora das reivindicações das mulheres pelo voto feminino, que obtiveram êxito parcial em 1927, no estado do Rio Grande do Norte, onde uma funcionária pública conseguiu pela justiça local o direito de votar naquelas eleições (KARAWEJCZYK, 2013). No entanto, o voto feminino para toda a extensão do território brasileiro, somente seria discutido com relevância em 1930, após a deposição de Washington Luiz pela Revolução de 30, quando Getúlio Vargas, ao assumir a chefia do Governo Provisório, designou, pelo decreto $\mathrm{n} 19.459$, de seis de dezembro de 1930, uma subcomissão legislativa para estudar e propor a reforma da lei e do processo eleitorais. É sabido que uma das reformas propostas era estender o direito de voto às mulheres (KARAWEJCZYK, 2013).

Conquista-se o voto feminino em 1932, com a promulgação do Código Eleitoral no dia 24 de fevereiro, que através do Decreto n. 21.076, instituiu-se na Justiça Eleitoral, o voto secreto e o voto feminino, cuja redação do artigo 2 deu-se desse modo: É eleitor o cidadão maior de 21 anos, sem distinção de sexo, alistado na forma desse código. Ressalta-se que o voto para as brasileiras não era obrigatório - a não ser para as funcionárias públicas (KARAWEJCZYK, 2013).

Uma possível interpretação que se faz é que a decisão de conceder o sufrágio feminino foi inegavelmente a situação oportuna aos detentores do poder, uma vez que se angariavam mais possibilidades de votos e aparentava certo alinhamento político e ideológico com outras nações no que considerava a modernidade naquele tempo. Outra interpretação dada é que a concessão do voto feminino foi um modo de responder às exigências da elite intelectual, que preconizavam uma aplicação das tendências europeias no Brasil, elite este que de pouco era composta por mulheres e por isso a importância de uma Revista jurídica composta de reconhecidos intelectuais nacionais, dar voz a uma mulher, a primeira advogada brasileira, Myrthes de Campos, em sua defesa ao 
voto feminino.

\section{$O$ voto feminino e seu debate na}

\section{Revista de Crítica Judiciária}

O debate sobre o voto feminino

e sua implementação apresenta-se na

Revista de Crítica Judiciária em três momentos. Duas são originadas a partir de decisões jurídicas com o tema principal sobre a concessão ou não do direito ao voto a mulher pleiteante. Após os julgados, há os comentários da advogada Myrthes de Campos, destacando a raridade desta fonte em termos de pesquisa científica, por apresentar a defesa por um viés jurídico de uma mulher sobre a possibilidade do voto feminino, especialmente pela sua luta como mulher para se tornar a primeira advogada do país, demonstrando o alcance da discussão sobre sufrágio feminino, que não passava apenas de um ideário isolado da elite nacional.

Já a terceira publicação é um artigo feito pela própria advogada sobre a defesa de um feminismo ao editor Clóvis Bevilacqua, pelo apoio do jurista a concessão do direito ao voto às mulheres e pelo espaço dado na Revista para contribuir e fortalecer o respaldo no campo jurídico ao voto feminino. Sabese que a esposa do editor, Amélia Bevilacqua, nesta mesma época também sofrera discriminação por ser mulher ao ser rejeitada na Academia de Letras Brasileira, causando-lhe grande indignação.

Inicia-se a análise do debate pelo julgado "As mulheres e o direito de voto-acepção da palavra "cidadão" empregada no art. 70 da Constituição Federal: somente designa o cidadão do sexo masculino- o elemento histórico desse dispositivo; as tradições do nosso direito; o verdadeiro papel e função da mulher na vida social', publicado na edição de fevereiro/março da Revista de Crítica Judiciária, em 1930, dois anos antes da concessão do direito ao voto feminino em todo território brasileiro. A decisão debatida foi emitida pelo Tribunal de São Paulo em 12 de fevereiro de 1929 pelo magistrado Esaú Corrêa de Almeida Moraes, a qual é transcrita na Revista.

A discussão é dada em torno da palavra "cidadão" e o seu emprego, no art. 70 da Constituição Federal de 1897, se este termo somente designava o cidadão do sexo masculino. $\mathrm{O}$ magistrado diz que seria apenas o sexo masculino e justifica-se ao considerar a 
intenção do legislador constituinte, de não estender à mulher o direito ao voto, bem como o legislador desconsidera qualquer questionamento de estender o sufrágio, por não haver qualquer reflexão ou debate anterior à composição do termo cidadão na Carta magna. Ademais, adentra-se no seu argumento do elemento histórico e sua importância na interpretação das leis para o melhor entendimento do legislador.

Segue-se pela decisão dado pelo julgador, a qual é alicerçada na ótica dominante à época de que não haveria outra interpretação, dadas as tradições do direito, segundo as quais a mulher, na ordem política não poderia ter maiores direitos do que na ordem civil. Ressalta que há para o homem maiores exigências para o exercício dos direitos na ordem política do que na ordem civil, visto que para o homem ter o direito de voto ou eletivo precisaria reunir vários requisitos, tais como, além da idade e da qualidade de cidadão brasileiro, não ser analfabeto, mendigo, praça de pré, religioso de ordens monásticas, etc., enquanto que para o exercício dos direitos civis seria exigido à idade de 18 anos.

Neste aspecto, o julgador ao concluir que no direito brasileiro haveria mais exigência em matéria política que em matéria civil, questiona-se sobre a mulher e sua posição de relevância. Destaca ainda se a mulher estaria na ordem civil sujeita a restrições no seu direito, quando, por exemplo, sob o poder marital, e se isso seria mais um indício da irrelevância da mulher para admissão no exercício dos direitos políticos, visto que, segundo ele, a esfera política preponderaria sobre a civil.

Outra questão que também o magistrado aborda em seu julgado é a prevalência na interpretação das leis das tradições dos costumes, no caso da sociedade à época. Ressalta ele, ainda, dentro de sua perspectiva dominante, esses costumes não permitem a colocação da mulher no mundo das paixões e sim as colocam no recesso doméstico ou na escola, longe dos contatos ásperos da vida, visto que apenas as virtudes femininas poderiam dar o encaminhamento moral e cívico a seus filhos, notadamente uma posição positivista e de conservação patriarcal. Mostra-se, assim, o magistrado ainda preso às posições tidas dominantes no seu tempo em relação à desconsideração da mulher como protagonista social em termos de igualdade com o homem.

Continua o julgador em sua 
visão retrógrada da mulher, enaltecendo a posição da mulher no lar, ao considerar uma tarefa difícil, mas gloriosa, uma vez que a velaria pela santidade do lar, acompanhando na escola ou no lar o movimento da criança, ao observar dos seus filhos e o seu desabrochamento das inclinações e das ideias, encaminhandoos para a felicidade e para o bem. O magistrado, por sua vez, conclui que a família seria a célula mater da sociedade, o alicerce onde se firma o edifício social, sendo necessária para a conservação da família em toda a sua integridade moral e cívica mesmo material, e para não se despedaçar em fragmentos deletérios, seria preciso, essencialmente, a conservação deste alicerce em solidez impecável para a mulher ser sempre, nos costumes, a operária bem dita, diligente, aquela que pela sua superioridade de afetos e de virtudes sempre teve e ainda teria, na organização da família e da sociedade, grande e benéfica influência.

O julgador não nega a mulher propositora da ação frente esses atributos que descreve em sua decisão. Ele diz que a proponente seria um caso de exceção, por fazer parte de um grupo de mulheres capazes, de pegarem em armas em defesa da pátria, de pugnarem pelas suas ideias na imprensa e na tribuna, de praticarem, enfim, outros atos que reclamariam a fortaleza de espírito e do corpo, como o exercício da advocacia, da medicina, engenharia, etc. No entanto, esta mulher encontrar-se-ia em um grupo à parte de inimaginável existência pelo legislador quando tratou da confecção da Constituição.

Ademais, o magistrado na sua decisão até considera uma possibilidade futura, na qual a humanidade pode assistir à confusão dos papéis. Entretanto, ele reafirma sua posição ao dizer que naquele momento ainda se cumpriria a conservar o que era visto à época, no tocante, à capacidade feminina.

Diante desses dizeres do magistrado, a advogada Myrthes de Campos inicia seu comentário relatando a sua surpresa, não pela conclusão contrária aos direitos políticos da mulher do julgado, mas pelo anacronismo dos fundamentos de tal decisão. Dá continuidade, ao dizer que a argumentação do magistrado de ordem política e moral pareceriam por completo deslocadas da época em que é aplicada, constituindo um raro fenômeno de sobrevivência de ideias dominantes de um passado remoto.

Reflete a advogada que o 
argumento do egrégio prolator da decisão, a despeito da fraqueza do sexo, professaria ainda o primitivo culto das leis, visto que, em tom de absurdo, elas seriam emanadas dos deuses e, então, sagradas e imutáveis, podendo coexistir dispositivos legais completamente antagônicos. Ela faz uma crítica feroz ao julgado, buscando respaldo no jurista Carlos Maximiliano, o qual dizia não ser decisivo para a interpretação das leis o elemento histórico apenas, prevalecendo contra ele o texto sistematicamente interpretado.

A advogada vai à leitura e à análise dos textos do Congresso Jurídico de 1922, onde foi vitoriosa a emenda favorável aos direitos políticos da mulher, e na imprensa da época que retratou trechos da Assembleia Constituinte a propósito da rejeição das emendas que concediam expressamente o voto a determinadas mulheres e não a todas. Ela relata que o deputado paulista Almeida Nogueira um membros da Assembleia constituinte, depois de defender energicamente o direito de voto das mulheres, declarou que votava contra as emendas que o concediam expressamente, porque julgava desnecessárias, uma vez que a Constituição do Império e o projeto constitucional em discussão não excluíam a mulher do eleitorado.

Traz a advogada que, em discurso pronunciado no Senado a 12 de Dezembro de 1927, elucidara completamente $\mathrm{o}$ assunto $\mathrm{o}$ senador Adolpho Gordo, um dos poucos constituintes sobreviventes à época, que julgaria indispensável fazer cessar essa lenda de que a Constituinte negara direitos políticos à mulher e recusara a garantir o direito de sufrágio a elas.

Declara Myrthes que foram 231 constituintes que tomaram parte na votação das emendas rejeitadas e que destes só um, o deputado Almeida Nogueira que fez declaração de voto pelos mesmos motivos de defesa que a advogada apresenta, favoráveis ao eleitorado feminino. Esclarece ainda que os que não fizeram declaração alguma, mas se manifestaram sobre o assunto por meio de discursos e emendas, mais de trinta seriam favoráveis ao sufrágio feminino.

Discute a advogada que não se pode por consequência afirmar que o elemento histórico repeliu o voto feminino, visto que não existiria proibição a respeito. Além do disposto no art. 72, nos seus parágrafos primeiro e segundo da Constituição de 1897, em 
que diz que ninguém pode ser obrigado a fazer ou deixar de fazer alguma coisa senão em virtude de lei e que todos são iguais perante a lei, a advogada defende que seria lógico que as mulheres poderiam ser eleitoras, bem como elegíveis.

Quanto aos motivos de ordem moral, ela relata se que criara um verdadeiro terror pela emancipação política do sexo fraco, e traz trecho completo que é dito no julgado do magistrado sobre o discurso feito por Pedro Americo (o imaginoso artista, acidentalmente feito político) que deixaria a outros a glória serena e angélica do gênero humano, contrário ao voto feminino na Assembleia Constituinte. Esse trecho expande-se nos seguintes conceitos que a advogada transcreve ipsis verbis, para não lhes tirar a originalidade:

Nós que aqui estamos transitoriamente, devemos receber a terra que nos serviu de berço, como um legado precioso e sagrado dos nossos avoengos e dela cuidar com todo o carinho e grande amor, esforçando-nos pela sua integridade moral, da moral antiga e pelo aperfeiçoamento, tanto quanto possível nos seus elementos materiais $\mathrm{e}$ intelectuais, a fim de que possamos lega-la aos nossos vindouros com a consciência tranquila de bem cumprida a nossa missão na terra, quando tivermos de abandoná-la em demanda do Além. Precisamos opor tenaz resistência, levantar um grande dique de encontro à onda devastadora que aí vem e que nos quer tragar, ameaçando de ruir o gigantesco trabalho construtos dos nossos antepassados na constituição da nossa nacionalidade para o que precisamos da mulher no seu posto de honra, onde os nossos maiores a colocaram, como sentinela e guarda do santuário da família, fundamento do organismo social, e como preceptora abençoada, que no lar, quer na escola, mormente na educação moral e cívica dos futuros servidos da Pátria. (REVISTA CRÍTICA JUDICIÁRIA, 1930, p. 145)

Myrthes prossegue, todavia que se deve ponderar a "moral antiga", pois ainda domina e pela sua procedência divina dominará, sendo a moral cristã e mesmo esta moral jamais condenou a ação social da mulher, cerceada pelo politeísmo greco-romano de que estavam impregnadas as instituições jurídicas da antiguidade clássica. Acrescenta que foi das fontes cristã e germânica que o direito moderno recebeu a influência de ideias que despertavam o apreço pela mulher, que elevavam a sua condição na família e na sociedade. Afirma ainda que o cristianismo, como no seu início um 
movimento francamente revolucionário, muito se utilizara da colaboração feminina, coerente com o princípio de igualdade humana perante Deus, base da doutrina fundante e abaladora do mundo antigo, combatendo os inveterados preconceitos de castas, de classes e de raças, e também feriu o privilégio do sexo.

A advogada cita São Paulo, por ser o pregador internacional do Cristianismo, o cidadão romano, que depois da misteriosa visão da estrada de Damasco, enfrentou a precária justiça humana na propaganda do novo credo, sempre foi exuberante de louvores à coragem e à dedicação das companheiras de luta. Ela lembra a Epístola 16 aos Romanos escrita por São Paulo, pois encerra o mais tocante reconhecimento a Junia, a Priscilla, a Olympia e entre muitas outras mulheres, especialmente a Phebe, ministra da Igreja em Cenchréa.

Ademais, Myrthes elucida que durante a Idade Média, o direito feudal que fundava o poder político sobre a propriedade, concedera às mulheres titulares de feudos, direitos iguais aos do homem: como eleitoras, administradoras da justiça e comandantes na guerra. Afirma que todos esses direitos das mulheres se passava sob o apoio da
16

Igreja. Exemplifica esse apoio com Papa Inocencio III que proibira os hospitaleiros de se subtraírem à jurisdição de Eleonora de Guyenna e fizera executar uma sentença arbitral proferida pela Rainha de França, mulher de Felipe Augusto, em uma questão entre duas ordens religiosas. Igualmente, lembra a história da Condessa Mathilde de Toscana, que era poderosa aliada da Igreja na questão das investiduras de benefícios, travada entre o Imperador da Alemanha, Henrique IV e o Papa Gregório VII, e a sua extremada dedicação à causa do Papado, a quem legara todos os seus vastos domínios na península Italiana.

Myrthes deslinda que em consequência do direito de propriedade, como privilégio de suserania tiveram as mulheres plena capacidade política na Idade Média e que por isso seria inadmissível a sua época a pretensão de negar no regime democrático, quando pelo menos teoricamente, triunfaria $\mathrm{o}$ sufrágio universal. Ressalta que essa negativa de direito às mulheres era vista como novidade perigosa, repelindo-se naquele momento o que já existira no passado.

Myrthes ressalta ainda o apoio de José Pereira Alves, Bispo de Niterói, 
que definia a situação da Igreja ante a evolução social, de que ela seria considerada orientadora, mas não imobilizadora, principalmente, no que dizia respeito ao feminismo não desintegrar a mulher do lar e aplaudia sem reservas, a mulher que trabalhava honradamente no comércio, na indústria, nas profissões liberais, nos cargos públicos. Por conseguinte, encerra a advogada "que razões não faltavam para que se deva votar a mulher" (REVISTA CRÍTICA JUDICIÁRIA, 1930, p. 147). Ironiza ao orientar "que se tranquilizassem as bondosas criaturas que pretendiam restaurar a clausura do gineceu” (REVISTA CRÍTICA JUDICIÁRIA, 1930, p. 147).

A segunda decisão " $O$ voto feminino e a jurisprudência" emitida pelo magistrado Octavio Celso de Novaes, em 29 de novembro de 1929, publicada em julho de 1930 na Revista de Crítica Judiciária, sobre a concessão do direito de voto a uma mulher, Isabel Iracema Feijó da Silveira, casada, diplomada pela Escola Normal do Estado e professora, cujos vencimentos lhe seriam pagos pelo Tesouro do Estado. Assim, esta mulher requerera a sua inclusão entre os eleitores do município, o qual habitava, sendo-lhe dado tal direito. $\mathrm{O}$ julgador inicia pela consideração que a presença da peticionaria em juízo não dependeria de autorização de seu marido, em vista do art. 247, parágrafo único do Código Civil de 1916 que estabeleceria que a mulher que ocupava cargos públicos deveria ser sempre autorizada pelo marido para tomada de atos cívicos.

O magistrado vai considerar diversos fatores a fim de conceder o direito ao voto a requerente, como a juntada de documentos probatórios de idade, residência e renda, útil $\mathrm{e}$ necessária para prova da capacidade eleitoral de qualquer cidadão. No entanto, vai desconsiderar qualquer observação ou análise sobre certos fenômenos psicológicos, sociais e morais, reveladores da superioridade ou inferioridade da inteligência, das energias e das aptidões da mulher em relação às do homem, estudadas por Tobias Barreto, Malaquias Gonçalves, Almeida Nogueira, Pedro Americo e muitos outros, e que porquanto preceitos constitucionais o resolviam sem a inspiração dos regulamentos tardios e mal organizados.

O julgador vai inspirar-se no artigo 69 da Constituição Federal de 1891, em que expressava como 
"cidadãos brasileiros" as pessoas nascidas no Brasil e no artigo 70 da citada Constituição, declarando serem eleitorais os cidadãos maiores de 21 anos, já a mulher era cidadã brasileira, em virtude daquele dispositivo constitucional, qualidade essa que não lhe havia sido negada pela lei anterior.

Assim, observa o magistrado que na Constituição Federal 1891 depois de proclamar a mulher integrada no exercício dos direitos de cidadã, determinava no parágrafo primeiro do referido art. 70 que não poderiam alistarse eleitores os mendigos, os analfabetos, os praças de pré, excetuados os alunos das escolas militares de ensino superior, os religiosos de ordem monástica, companhias ou comunidades de qualquer denominação, sujeitos a voto de obediência. Considerava que entre os excetuados nesse preceito constitucional, não ficara compreendida a mulher, cujos direitos inerentes ao exercício de cidadão já haviam sido clara e expressamente assegurados pelo art. 69 citado.

Outra questão que o magistrado levanta é que nenhuma dúvida poderia decorrer do vocábulo "cidadãos", empregado pelo art. 70, compreendendo ambos os sexos, uma vez que não só ele era usado em vários artigos da Constituição Federal 1891, como em vista do princípio da propriedade do gênero masculino sobre o feminino, erigido em postulado pelos cultores da língua portuguesa. Seria, segundo ele, mais intuitivo e melhor correspondente ao conceito legal, aceitar-se a compreensão da Constituição Federal de 1891, empregando em diversos artigos o vocábulo "cidadãos" compreendeu ambos os sexos, porque no seu art. 73 garantiria o acesso dos brasileiros aos cargos públicos e no art. 60, revogado pela reforma de 1926, declararia que compete aos juízes ou tribunais federais processar e julgar os litígios entre um Estado e cidadãos do outro, ou entre cidadãos de Estados diversos, diversificando as leis destes. Por conseguinte, ante tais disposições constitucionais defende o magistrado a impossibilidade de afirmar que o cargo público era e seria privilégio do homem, e que semelhantes litígios só pertenceriam à jurisdição federal, quando este fosse autor ou réu porque a mulher não gozaria direito de cidadão.

Prossegue o julgador contrário a decretação de que a mulher jamais poderia incorrer na sanção penal ou que não teria capacidade para ser titular de 
direitos e obrigações na ordem cívica. Considera que o Código Penal, por repetidas referências aos delinquentes e criminosos sem nunca empregar as palavras "as delinquentes", "as criminosas", e no seu art. 27 diz que quando o crime for cometido por mais de um delinquente, os bens de todos seriam hipotecados desde o momento do crime, artigo revogado pelo art. 24 do regulamento a que se refere o decreto n.16.272, de 27 de fevereiro de 1924 . Como, igualmente, o magistrado expõe que, da mesma forma o Código Civil, nos seus artigos 2, 4, 5, 6, 9 e 185 assim se expressava que todo o homem seria capaz de direitos e obrigações, que a personalidade do homem começaria do nascimento com vida, mas a lei colocava a salvo desde a concepção os direitos do nascituro, que os loucos de todo o gênero, os surdos-mudos que não podiam exprimir a sua vontade, os ausentes declarados tais por ato do juiz, seriam incapazes relativamente os maiores de dezesseis anos e menores de 21, os pródigos, os selvícolas, aos 21 anos completos acabaria a menoridade, ficando o indivíduo habilitado para todos os atos da vida civil, para o casamento dos menores de 21 anos, sendo filhos legítimos seria mister o consentimento de ambos os pais, etc.

Em face destas disposições expressas no Código Civil, o julgador ressalta que ninguém se lembrara, ainda, de negar a existência entre o homem e a mulher a mais ampla e perfeita igualdade, relativa ao uso e gozo dos direitos privados, nem se deixara por isso de garantir o direito do nascituro, de reconhecer a maioridade da mulher e que esta seria capaz de direitos e obrigações, que sua capacidade civil começaria no nascimento, e decretar a incapacidade da louca, da menor, da pródiga, da ausente, etc.

Igualmente, na esfera penal, ressalta o magistrado, embora o Código apenas fizesse referências a criminosos, a mulher foi sempre imputável, com responsabilidade plena na perpetração dos seus delitos, sem que advogado algum, por mais notável e ampla que fosse a sua defesa, cogitasse da irresponsabilidade de sua constituinte, por ter o dispositivo penal referindo-se aos seus infratores, deixado de empregar o vocábulo "criminosas".

A Constituição Federal 1891 segue o magistrado, não proibiria em nenhum de seus textos que a mulher fosse incluída eleitora, podendo votar e ser votada, porquanto a proclamando 
cidadã brasileira, reconhecera a todos os cidadãos o direito de se alistarem eleitores especificando quais restrições, as exceções no parágrafo primeiro e seus números do seu art. 70. Dessa forma, tendo a mulher adquirido os direitos de cidadão em virtude do estatuído no art. 69 aludido, só podem eles ser suspensos ou perdidos pelo concurso das condições previstas no art. 71 , parágrafo 1 , letras a e b, parágrafo 2 letras a e b. Se a Constituição no parágrafo 3, do art. 71 , cometera a uma lei ordinária a determinação das condições de reaquisição dos direitos de cidadão, para aquisição destes, estabelecera simplesmente a condição do nascimento no Brasil, além dos expressos nos números 2, 3, 4, 5 e 6 do art. 69, elucida o julgador. Assim, não tendo a Constituição nas suas exceções do art. 71, excluído a mulher do quadro daqueles a quem negara capacidade para o exercício dos direitos políticos, não caberia a ele julgador senão aplicar a lei para garantia do direito lesado, sem o influxo das oportunidades, sem atenção a esta ou aquela conveniência.

Sobre as exceções, o magistrado esclarece que quando a lei abre exceções ou restringe, apenas abrangeria os casos que especificaria, visto no Código Civil em seu artigo 6. Se a lei quisesse excluir a mulher do sufrágio político o teria expressado do mesmo modo que a expressou quanto aos analfabetos, as praças de pret., mendigos e religiosos. Ademais, continua o julgador a falta de independência e isenção que serviram de base ao legislador para determinar as exceções estabelecidas no parágrafo primeiro e seus números do art. 70, não envolvera a mulher, nem poderia à época, em que, com a evolução verificada na órbita social, ela afastada do lar, exercitava vantajosamente a sua atividade no comércio, nas indústrias, na advocacia, na medicina, na aviação, etc., concorrer para lhe ser negado o exercício do voto que lhe foi amplamente assegurado pela Constituição Federal.

Myrthes vai considerar que uma lei que viesse expressamente conceder o voto às mulheres, apesar de ter o mérito de dirimir imediatamente a questão sobre a capacidade da mulher para votar, teria mero caráter declaratório, visto que à época a Constituição Federal 1891 já tinha outorgado a capacidade política para as mulheres. No entanto, mesmo com a não exclusão da mulher como cidadão brasileiro, continua a advogada, respaldada pelo texto constitucional, de 
grande clareza, caberia ao poder judiciário interpretar essa questão, ou melhor, aplicá-la, à medida que se fariam apresentados os casos concretos, com os pedidos de inclusão no alistamento eleitoral de mulheres.

Por conseguinte, Myrthes demonstra, a partir da apreciação sistemática do Código Civil à época vigente, que a incapacidade relativa da mulher casada, por ele próprio admitida, seria quase letra morta, significando apenas restrição de direitos o que também, sofreria o marido, que poderia ser até substituído na chefia da sociedade conjugal pela mulher, nos casos previstos pelo art. 251, n. I, II e III do Código. Esta incapacidade fictícia e restrita aos interesses de família, não acreditava a advogada que pudesse atingir à mulher como membro da associação política, sendo-lhe conferidas pela Constituição as prerrogativas da cidadania. Assim, segundo ela, dispensável para que possa a mulher ser eleitora, a autorização decorrente do poder marital, vestígio quase extinto da manus romana e do mundium germânico. E ela lembra o acerto dos países onde por lei especial se concedeu o voto às mulheres não se cogitava do casamento, nem constava que a autoridade marital teria perturbado o eleitorado feminino.

$\mathrm{Na}$ aplicação do art. 69 da Constituição Federal 1891, distingue a advogada, que sempre se teria empregado quer no texto constitucional quer na legislação civil, o masculino, de modo geral, com referência aos indivíduos de ambos os sexos. Myrthes, igualmente, lamenta, sem nenhuma preocupação feminista, que por um simples preconceito tivera já há muito repelido a Academia de Letras Brasileira a possibilidade de ter como sócia correspondente a filóloga Carolina Michaelis de Vasconcellos.

Myrthes igualmente considera extravagante a doutrina que reclama uma lei para que se possa praticar ato não proibido, no caso que deveria ter uma lei para que proibisse as mulheres de votar em seu tempo. Ela respalda sua contrariedade a essa doutrina através do disposto no art. 72, parágrafo $2 \mathrm{da}$ Constituição Federal 1891, o qual dizia que ninguém seria obrigado a fazer ou deixar de fazer alguma coisa senão em virtude da lei. Já quanto à intervenção do poder judiciário, a advogada destaca o absurdo de sua época da necessidade das mulheres recorrerem a decisões judiciais para poderem se alistar ao voto. 
Myrthes traz uma deliberação do Ministro da Guerra à época, autorizando os Comandantes das sexta e sétima circunscrições militares a admitirem como membros das respectivas juntas de alistamento, duas funcionárias públicas, Aureliana Amélia dos Santos, que exercia o cargo de escrivão de paz e oficial de registro civil em Laranjeiras, Estado de Sergipe, e Sylvia Medeiros dos Santos, que ocupava cargo idêntico em Piliar, Estado da Paraíba. Frisa, assim, os progressos do posicionamento da mulher no funcionalismo público.

O texto de Myrthes de Campos dentro do tema do sufrágio feminino, Clovis Bevilacqua e a emancipação jurídica da mulher publicada em dezembro de 1932, trazendo a figura do intelectual Clóvis Beviláqua como defensor da emancipação jurídica da mulher. Fala-se dos princípios da perfeita coexistência de direitos dos cônjuges, de modo a não ser aniquilada a personalidade da mulher, como esposa e como mãe, repudiando a inferioridade intelectual da mulher. A advogada conceitua a abordagem de Beviláqua quanto da controvérsia sobre a nacionalidade de brasileira casada com estrangeiro, em que chegou à conclusão, que à época do artigo já era indiscutível perante o Código Eleitoral art. 3, que a mulher não perde a cidadania pelo casamento. No Projeto do Código Civil, como destacou Myrthes, convertido em lei, estabeleceria ganhos à causa feminina pela sua emancipação, como a plena capacidade da mulher solteira, de maior idade.

\section{Considerações Finais}

A Revista de Critica Judiciária apresentou-se como uma perpetuação do ideário dos intelectuais do início do século XX, como Clóvis Beviláqua. Resgata-se a importância de análise dessa fonte como dado histórico, atentando para suas peculiaridades do recorte temporal a qual esta se insere, um debate sobre o sufrágio feminino, principalmente, pela visão da primeira advogada brasileira Mythes de Campos.

O contexto da mulher desse período foi permeado de enlaces de certo modo progressistas, no que tange a expansão do espaço social dado, e conservador, na resistência ao acesso intelectual e político.

Pelas perspectivas conservadoras defendidas na Revista, tem-se uma visão positivista da mulher, 
coerente com seu tempo, bem como um uso da interpretação da lei pelas intenções do legislador constituinte, as quais refutariam o direito do voto feminino.

Já a defesa, de viés progressista, do sufrágio, exercido na pessoa da advogada Myrthes de Campos, é um tanto controversa ao levantar, além de elementos históricos, o próprio Cristianismo, como justificativa da igualdade entre homens e mulheres. $\mathrm{O}$ que demonstra que uma da crença em um direito pautado pelos cânones da Igreja, traduzindo certa alienação por parte da advogada da sua realidade, como integrante de um grupo intelectual restrito ao campo jurídico. Traduz-se essa argumentação em uma nítida falta de compreensão das mulheres como um todo neste debate, abarcando apenas as notáveis, refletido pelo não diálogo dos textos com os movimentos sociais feministas defensores do voto da mulher nesta época.

Todavia, o texto traz novos ares sobre uma compreensão da busca pela igualdade, especialmente a jurídica. Além de mostrar a criticidade no debate jurídica no período da Revista através do debate entre magistrados e a da advogada Myrthes, no qual se mostra uma realidade desconhecida do campo jurídico atual, no que tange ao saber histórico da origem de seus institutos e atores.

\section{REFERÊNCIAS}

BOURDIEU, Pierre. O Poder Simbólico. Rio de Janeiro: Bertrand Brasil, 2001.

BRASIL. Constituição da República dos Estados Unidos do Brasil de 1891. Disponível em:

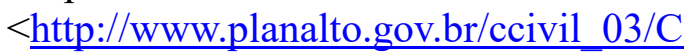
onstituicao/Constituicao91.htm.>.

Acessado em 31 de ago. 2016.

BRASIL. Decreto n. 2.848 de 7 de dezembro de 1940. Disponível em: $<$ http://www.planalto.gov.br/ccivil_03/d ecreto-lei/del2848.htm>. Acessado em 31 de ago. 2016.

BRASIL. Decreto n. 21.076 de 24 de fevereiro de 1932. Disponível em: $<$ http://legis.senado.gov.br/legislacao/Li staPublicacoes .action? id $=33626>$.

Acessado em 31 de ago. 2016.

BRASIL. Lei de 16 de dezembro de 1830. Disponível em: $<$ http://www.planalto.gov.br/ccivil_03/1 eis/lim/lim-16-12-1830.htm $>$. Acessado em 31 de ago. 2016.

BRASIL. Lei $n^{\circ} 3.071$ de $1^{\circ}$ de janeiro de 1916. Disponível em: < http://www.planalto.gov.br/ccivil 03/lei s/13071.htm >. Acessado em 31 de ago. 2016.

BRASIL. Regulamento do Decreto $n$. 16.272. Disponível em: 
$<\underline{\text { http://legis.senado.gov.br/legislacao/Li }}$ staNormas.action?numero $=16272 \&$ tipo norma $=$ DEC\&data $=19231220 \&$ link $=\mathrm{S}$ >. Acessado em 31 de ago. 2016.

ISMÉRIO, Clarisse. Mulher: a moral e

o imaginário: 1889 - 1930. Porto

Alegre: EDIPUCRS, 1995.

KARAWEJCZYK, Mônica. As filhas de Eva querem votar: dos primórdios da questão à conquista do sufrágio feminino no Brasil. Tese de Doutorado, Universidade Federal do Rio Grande do Sul, Instituto de Filosofia e Ciências Humanas, Programa de Pós-Graduação em História. Porto Alegre, 2013.

\section{REVISTA DE CRÍTICA} JUDICIÁRIA. Rio de Janeiro: Clovis Bevilaqua, 1924 - 1946.

ROUSSEAU, Jean-Jaques. Emílio ou

Da Educação. Rio de Janeiro: Bertrand Brasil, 1992. 